\title{
Empirical Study on People's Perception Regarding Introduction of GST in India
}

\author{
Dr. Sarbapriya Ray \\ Associate Professor, Dept. of Commerce, Vivekananda College, under University of Calcutta, India
}

\begin{abstract}
Taxation system of India had a long history which started from the prologue of 'Jizya' by Aurangzeb to new born GST (Goods and Service Taxes). Recently, GST is one of the biggest tax reforms in the country postindependence which will integrate all the state economies and boost overall growth and would introduce a uniform taxation law across states and different sectors in respect to indirect taxes. Goods \& Services Tax Law in India is a comprehensive, multi-stage, destination-based tax that is levied on every value addition. This study which includes a theoretical discussion with empirical evidences highlights the overall overview of GST system in India. The main focus of this study is to have a general understanding about the newly introduced GST tax regime in India and also to assess the perception of general people surrounded in different segments of our society regarding the Goods and Service tax. The Government must put in more effort to ensure that consumers have a clear understanding and develop a positive perception towards GST, leading to its acceptance.
\end{abstract}

Keywords: GST, India, indirect taxes, people.

DOI: $10.7176 /$ RHSS/10-13-05

Publication date:July $31^{\text {st }} 2020$

\section{Introduction:}

Taxation system of India had a long history which started from the prologue of 'Jizya' by Aurangzeb to new born GST (Goods and Service Taxes). Recently, GST is one of the major tax reforms in the country postindependence which will integrate all the state economies and boost overall growth and would introduce a uniform taxation law across states and different sectors in respect to indirect taxes. This would make supply of goods and services, hassle free throughout the country. Goods \& Services Tax in India is a comprehensive, multi-stage, destination-based tax that is levied on every value addition. Clauses 366 (12A) of the constitution Bill defines GST as "goods and service tax" which means any tax on supply of goods, or services or both except taxes on the supply of the liquor for human consumption. Further the clause 366 (26A) of the Bill defines Services which means anything other than Goods. The chief objective of GST is to introduce one indirect tax instead of several indirect taxes so far levied by Central Government and State Government/Union Territories. Optimistically, it will prevent cascading of taxes as Input Tax Credit will be available across goods and services at every stage of supply facilitate to create a unified common national market for India, giving a boost to foreign investment, reduce the multiplicity of taxes that are, at present, governing our indirect tax system leading to simplification and uniformity. The government has proposed a 4-tier tax structure for all goods and services under the slabs- $0 \%$ (Exempted categories) $\quad 5 \%$ ( Commonly used Goods and Services), $12 \%$ ( Standard Goods and Services fall under 1st Slab), 18\% (Standard Goods and Services fall under 2nd Slab) and $28 \%$ ( Special category of Goods and Services including Luxury Goods). After the recent revision of GST rates, these are the commodities that fall under the four tax slabs along with those that do not attract any tax.

Table: 1: Types of Goods and Service Tax in India

\begin{tabular}{|l|l|}
\hline CGST $\rightarrow$ & $\begin{array}{l}\bullet \text { CGST stands for Central GST } \\
\text { - This is applicable on supplies within the state } \\
\bullet \text { Tax collection will be shared to Centre }\end{array}$ \\
\hline SGST $\rightarrow$ & $\begin{array}{l}\text { SGST stands for State GST } \\
\text { — This is applicable on supplies within the state } \\
\text { — Tax collection will be shared to State }\end{array}$ \\
\hline $\begin{array}{l}\text { UTGST } \\
\text { - UTGST stands for Union Territory GST } \\
\text { — This is applicable on supplies within the Union Territory } \\
\text { — Tax collection will be shared to Union Territory }\end{array}$ \\
\hline IGST $\rightarrow$ & $\begin{array}{l}\text { IGST stands for Integrated GST } \\
\text { - This is applicable on interstate and import transactions } \\
\bullet \text { Tax collection will be shared between Centre and states. }\end{array}$ \\
\hline
\end{tabular}

2. Literature Review on people's perception regarding introduction of GST in India There are a few literatures which concentrate on GST which are briefly discussed below:

Ehtisham Ahmed and Satya Poddar (2009) observed that introduction of GST in India will provide transparent 
tax system with increase in output and productivity of economy in India subject to the rational design of GST. R. Vasanthagopal (2011) concluded that switching to seamless GST from current complicated indirect tax system in India will be positive step in becoming Indian economy. Success of GST will lead to its acceptance by more than 130 countries in world and a new preferred form of Indirect Tax System in Asia also. Pinki, Supriya Kamma and Richa Verma (2014) studied concluded that the new NDA government in India is positive towards implementation of GST and it is beneficial for central government, state government and as well as for consumers in long run if its implementation is backed by strong it infrastructure. Jai Parkash ( 2014) mentioned that the GST at the Central and the State level are expected to give more relief to industry, trade, agriculture and consumers through a more comprehensive and wider coverage of input tax set-off and service tax set off, subsuming of several taxes in the GST and phasing out of CST. Agog Mawuli (2014) found that GST is not good for low-income countries and does not provide broad based growth to poor countries. If still these countries want to implement GST then the rate of GST should be less than 10\% for growth. Garg,G (2014)concluded that a tax is not a voluntary payment or donation, but an enforced contribution, exacted pursuant to legislative authority" and is any contribution imposed by government whether under the name of toll, tribute, impost, duty, custom, excise, subsidy, aid, supply, or other name. Kumar,N (2014) states that GST will be charged for all the goods and services except for those items that are exempted from the GST. The author further stated that the proposed GST will be implemented as dual model GST. Venkatachalam, S., (2014) analyzed a study to know the post effects of goods and service tax on the national growth of ASEAN countries and found that Philippines and Thailand show significant negative relationship with their nation's development. Meanwhile, Singapore shows a significant positive relationship. Nishitha Guptha (2014) in her study stated that implementation of GST in the Indian framework will lead to commercial benefits which were untouched by the VAT system and would essentially lead to economic development. Palil, M. R., \& Ibrahim, M. A. (2011) summaries that public are expecting a $4 \%$ hike in price of goods if the GST is implemented. Less information is provided by the government to public. The govt. c should take necessary steps to make public aware about the positive impact of GST. Sehrawat, M., and Dhandha, U. (2015) concluded that GST is simple and transparent tax system which will help to generate the employment opportunities and increase the GDP of Indian economy by $1-1.5 \%$. They also concluded that if GST will implement successfully it can use as an effective tool for framing fiscal policy also. Kaur, J., (2016) concluded that there will be both positive and negative impact of GST in India. Prices of the some commodity will fall down while the prices of some commodity will go up. Inflation can also become a threat due to GST. Vineet Chauhan (2017) seeks to evaluate the awareness of the business owners about GST difficulties they face to encase of the current awareness about it. 148 small business owners were analyses in order to identify the awareness about GST from Rajasthan state and the kind and extent of relief provided and the implementation of the provision under GST Law. Karthick R et.al(2017) found that consumers feel that the tax rates are high for the products of daily use. They further found that consumers feel that method followed for GST is highly complicated and periodic evaluation of tax rates is required. Further they concluded that GST can be successful only when business persons have a right understanding of how GST has to be charged to the consumers. Manoj Kumar Agarwal (2017) found that people feel that GST has increased the legal compliances and it will increase the tax collection of the government. He further found that GST has increased the tax burden of businessmen and suggested that efforts should be made on the part of the government to ensure people have a proper understanding of the goods and services tax implemented in India. Anshu Ahuja (2017) found that consumers are satisfied that goods and services tax will reduce the tax evasion in the country and will increase the transparency in the tax structure. He further suggested that government should give some relaxation to farmers and small scale business to avoid the adverse impact of goods and services tax on their income level. Gowtham Ramkumar (2017) concluded that consumers are left with less money after GST, rise in inflation level and fall in prices of certain goods after GST implementation. He further concluded that GST rates will have a significant impact on the spending ability of the consumers and suggested that benefits of input tax credit must be transferred by the companies to the consumers.

\section{Statement of the problem:}

India intends to adopt a dual GST which will be imposed concurrently by the central and states. The proposed dual structure GST, seeks to simplify the complex indirect taxation system in India and create a common national market by bringing down fiscal barriers between the states. GST is a new tax system which is moving towards an efficient indirect tax regime. It becomes imperative for consumers to keep themselves updated with this new tax in country's tax landscape. Thus the present study seeks to investigate the perceptions towards GST among the consumers has been carried out.

GST will be a game changing reform for the Indian economy, as it will create a common Indian market and expected to reduce the cascading effect of tax on the cost of goods and Services. It will impact the tax structure, tax incidence, tax computation, tax payment, compliance, credit utilization and reporting, leading to a complete overhaul of the current indirect tax system. Not only business decision but also the family budget decision is 
going to be influenced by GST. The structure of GST rates, the process of Taxation, the benefit of GST, everything has been elaborated by the govt. to the public including retailers, business persons, employees and laymen. We have been in several months on implementation of GST in our economy. However, certain questions remain unanswered. Certain disorder exists in the mind of laymen which is neither described nor cleared. The retailers are in confusion on pricing of products and rate of GST to be charged on the products and services. The govt. had given enough time for the retailers to sell off their existing stock at the previous prices, but they are exploiting this opportunity by selling the products at GST rate. Whatever reforms are implemented, they are increasing the tax burden of public. The manufacturers and retailers are getting profit. Hence a detailed study ha $\mathrm{s}$ to be conducted in order to check the awareness level of public towards GST. In this study we attempt to find answers to certain questions they are:

- What is the intensity of awareness regarding GST among public surrounded in our Indian society?

- Does the public confront any issues with the accomplishment of GST?

\section{Novelty of the research:}

Numerous research studies focused on the impact of goods and services tax to the Indian economy. Correspondingly, there are also many research studies which focused on how goods and services tax will benefit and cost different sectors of the economy. A small number of research studies studied the consumer perception towards goods and services tax but do not take an economic approach in studying the consumer perceptions. This study is exceptional because it seeks to study the consumer perception towards goods and services tax based on the economic variables like disposable income and spending ability along with their satisfaction towards goods and services tax.

\section{Need and Significance of the study}

GST is expected to give a major relief to industry, trade, agriculture and consumers through comprehensive and wider coverage of input tax set off (both on goods and services), subsuming of multiple taxes. It will ensure a simpler tax regime with fewer taxes, rates and exemptions. A simplified tax regime coupled with simple articulate and largely online procedures will leads to improved tax compliances with lesser scope for mistakes. GST is the best opportunity for consumers that help to increase the purchasing power. GST implementation will leads to immense scope for each consumers and to keep pace with the changing global indirect tax scenario.

\section{Objectives of Study:}

(a) To study the concept of GST in India.

(a)To analyse customer's general perception regarding Goods and Service Tax (GST) introduced in India.

(b)To assess customers' view regarding importance of GST in selected area of South Kolkata, India.

(c)To find out the perception and their views on newly implemented taxation system.

(d)To find out what professionals and servicemen and students think about GST.

Therefore, this study which includes a brief theoretical discussion above along with empirical evidences highlights the overall overview of GST system in India. The main focus of this study is to have a general understanding about the newly introduced GST tax regime in India and also to assess the perception of general people surrounded in different segments of our society regarding the Goods and Service tax in India.

\section{Research Methodology:}

GST is the newest tax reforms in India which is one of the novel research areas in Indian business society. There is hardly any empirical study performed on this topic in this locality undertaken in our study. So with the help of the study, we are optimistic to have an insight into the significance of popular perception about GST introduced in India. After reviewing the literature, we found that there is so far no study which concentrates on empirical analysis of the perception of general people regarding introduction of goods and service taxes in India.Based on the research gap, we have taken up the following objectives to give momentum of the study of this chapter.

\subsection{Developing a Research Plan:}

The present study is exploratory in nature. As GST is the newest tax reformed and there is hardly any study conducted, so a study about the perception of people about GST is needed to be done. The data for this study has been collected through self-administration. Due to time limitation and other constraints direct personnel interview study method is used and a questionnaire was framed. It consumes less time and pretty important from the point of view of information, easier to analyse and interpret.

Development of research plan has the following steps:

\subsubsection{Sample design:}

The complete study of all items in the population is known as a census inquiry. At first, different people have been selected in the locality that has minimum knowledge about GST. The number of respondents was 60 which 
include different professionals, servicemen, customers and businessmen.

7.1.2. Sample size:

The study has been conducted among 60 people in South Kolkata region of West Bengal, India. The responses were captured from respondents on a 5 point Likert scale.

7.1.3. Sampling Method:

The sampling method was Judgment Sampling (only those respondents were chosen who had some knowledge about GST)

7.1.4. Data Collection:

Questionnaire:

The data has been collected by administering a structured schedule of questions. The questions are generally framed by 5 point Likert Scale and answers by respondents in form of Agree, Disagree, Neutral, Strongly Agree and Strongly disagree. The Questionnaire has been prepared for studying the customers' perception towards the Goods and Services Tax in South Kolkata area of West Bengal, India. For the present study, questionnaire method is used to collect primary data. This questionnaire is self-administrated questionnaire and it is divided into two sections - Section A and Section B.

Section A consist the questions regarding Personal Information. For ex. Name, Age, Gender, Qualification, Occupation etc.Section B consist the questions which fulfil the research objectives and it contains 12 questions. In the present research work, mathematical tools are used. In this method are including the percentage and simple average has been used to analysis and interpretation or collection of data. A Percentage frequency distribution is a display of data that specifies the percentage of observations that exist for each data points. It is particularly useful method of expressing the relative frequency of survey responses and other data.

7.1.5. Limitations of study:

With a view to analyse the shortcomings of the present study, it can be acknowledged that due to paucity of time, the sample size is restricted to 60 which seems to be small in size and this shortcomings can be recovered while we will undertake a broader research in this area in future allowing the system run for a longer period of time. In times of collecting data, we have discovered that some people do not have any idea regarding GST as they are not accustomed to use this newer tax system-GST system. So it was very difficult to collect more information on this topic.

\section{Analysis of Result:}

In this section, efforts have been made to analyse and interpret the collective data towards perception of people on "Goods and Service Tax " through questionnaire in South Kolkata area of west Bengal, India.

First of all the collected data have been presented in tabular form and thereafter, it is analysed with the help of Pie Charts.A brief description of analysis and interpretation given below:

In Table 8.1, an attempt has been made to classify the respondents on the basis of their age factor.

Table No. 8.1: Classification of respondents according to age

\begin{tabular}{|l|l|l|l|}
\hline Serial Number & Age Group(years) & Number of respondents & Percentage \\
\hline 1 & Below 25 & 16 & $27 \%$ \\
\hline 2 & $25-40$ & 29 & $48 \%$ \\
\hline 3 & Above 40 & 15 & $25 \%$ \\
\hline & Total & $\mathbf{6 0}$ & $\mathbf{1 0 0}$ \\
\hline
\end{tabular}

Sources: Data collected from primary sources through questionnaire method

According to the above data, maximum respondents belong to the group 'between 25-40 years of age' which is approximately $48 \%$ of the total respondents followed by the respondents who belong to the group 'below 25 years of age'.

Figure: 8.1: Pictorial presentation of classification of respondents according to age

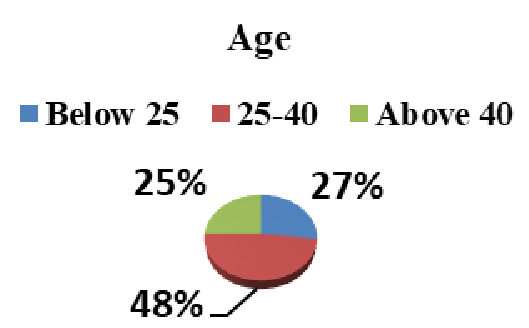

In Table 8.2, an attempt has been made to classify the respondents on the basis of academic qualification. The qualifications have been divided into four Categories - Secondary (10 standard), Higher Secondary (12 standard), Graduation, Post-Graduation and Any other qualification. The description of this as below: 
Table 8.2: Classification of respondents according to Qualification

\begin{tabular}{|l|l|l|l|}
\hline Serial Number & Qualification & Respondents & Percentage \\
\hline 1 & Secondary(10 standard) & 1 & $2 \%$ \\
\hline 2 & Higher Secondary(12 standard) & 5 & $8 \%$ \\
\hline 3 & Graduation & 46 & $77 \%$ \\
\hline 4 & Master and Others & 8 & $13 \%$ \\
\hline & Total & $\mathbf{6 0}$ & $\mathbf{1 0 0}$ \\
\hline
\end{tabular}

Sources: Data collected from primary sources through questionnaire method

The analysis of above data shows that maximum respondents (77\% of total respondents) surveyed who are acquainted with system of GST is graduate. It shows that other respondents having lesser or higher qualifications have less familiarity with GST vis -a -vis less interested about the mechanism of GST.

Figure: 8.2: Pictorial presentation of classification of respondents according to Qualification

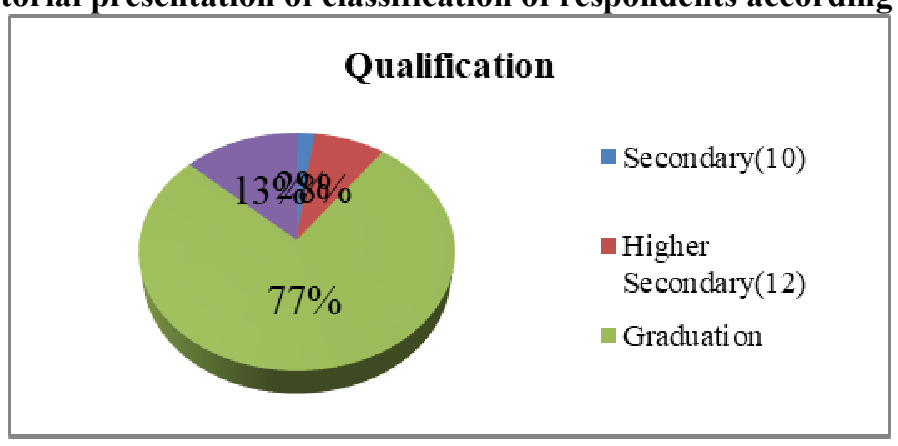

Table 8.3: Classification of respondents according to Gender

\begin{tabular}{|l|l|l|l|}
\hline SI no. & Gender & Respondents & Percentage \\
\hline $\mathbf{1}$ & Male & 42 & $70 \%$ \\
\hline $\mathbf{2}$ & Female & 18 & $30 \%$ \\
\hline & Total & $\mathbf{6 0}$ & $\mathbf{1 0 0}$ \\
\hline
\end{tabular}

Sources: Data collected from primary sources through questionnaire method

Eventually, table 8.3 presents that most of the respondents surveyed are male by gender which accounted for $70 \%$ of the total respondents. It is quite evident that in countries like India , most of the persons residing in a country are involved in business and its associated activities like finance, taxation, marketing procedures etc.

Figure: 8.3: Pictorial presentation of classification of respondents according to Gender

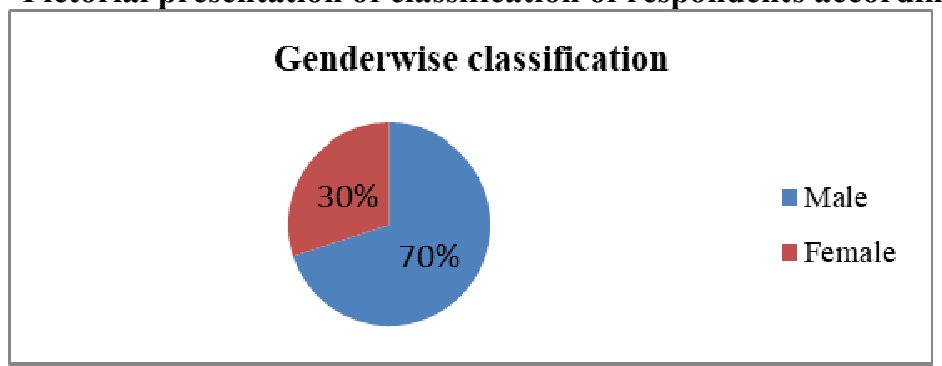

Therefore, it is obvious that there is the chance of reflecting true picture of perception regarding GST mechanism in India as male respondents are dominant in expressing their views on GST.

Table 8.4: Occupation-wise classification of respondents

\begin{tabular}{|l|l|l|l|}
\hline Serial Number & Occupation & Respondents & Percentage \\
\hline 1 & Businessman & 22 & $37 \%$ \\
\hline 2 & Services \& Professional & 17 & $28 \%$ \\
\hline 3 & Customers \& Students & 21 & $35 \%$ \\
\hline & Total & $\mathbf{6 0}$ & $\mathbf{1 0 0}$ \\
\hline
\end{tabular}

Sources: Data collected from primary sources through questionnaire method

While surveying the perception of respondents coming from different segments of the society, it has been prominently observed that majority of the respondents( $37 \%$ of the total respondents) are businessmen who have little bit familiarity about mechanism of GST followed by customers and students( $35 \%)$. 
Figure: 8.4: Pictorial presentation of Occupation-wise classification

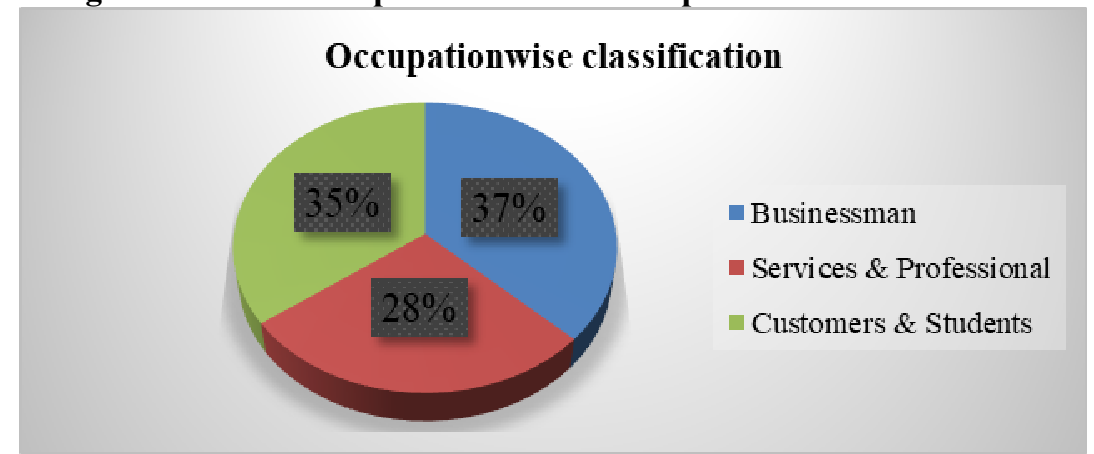

In Table 8.5, an effort has been initiated to analyse the respondents' perception towards the statement "Goods and Service Tax is a very good tax reforms made so far in India". The Perception level of the respondents has been divided into five categories following Likert five point scale- Strongly Agree, Agree, Neutral, Disagree, Strongly Disagree. The description of this as below

Table No.8.5: People's perception regarding Goods and Service Tax

\begin{tabular}{|l|l|l|l|}
\hline Serial number & Response & Number of respondents & Percentage (\%) \\
\hline 1 & Strongly Agree & 14 & $24 \%$ \\
\hline 2 & Agree & 36 & $60 \%$ \\
\hline 3 & Neutral & 04 & $6 \%$ \\
\hline 4 & Disagree & 04 & $6 \%$ \\
\hline 5 & Strongly Disagree & 02 & $4 \%$ \\
\hline & Total & $\mathbf{6 0}$ & $\mathbf{1 0 0}$ \\
\hline
\end{tabular}

Sources: Data collected from primary sources through questionnaire method

From the survey conducted, it has been found that is shows maximum respondents(about $60 \%$ of total respondents) have agreed with the statement that Goods and Service Tax is a very good tax reforms made so far in India, $24 \%$ of respondents have strongly agreed with statement. Among the respondents, only $10 \%$ of the respondents are having disagreement with it. So it can be concluded that majority agreed with the statement.

Figure: 8.5:Pictorial presentation of people's perception regarding Goods and Service Tax

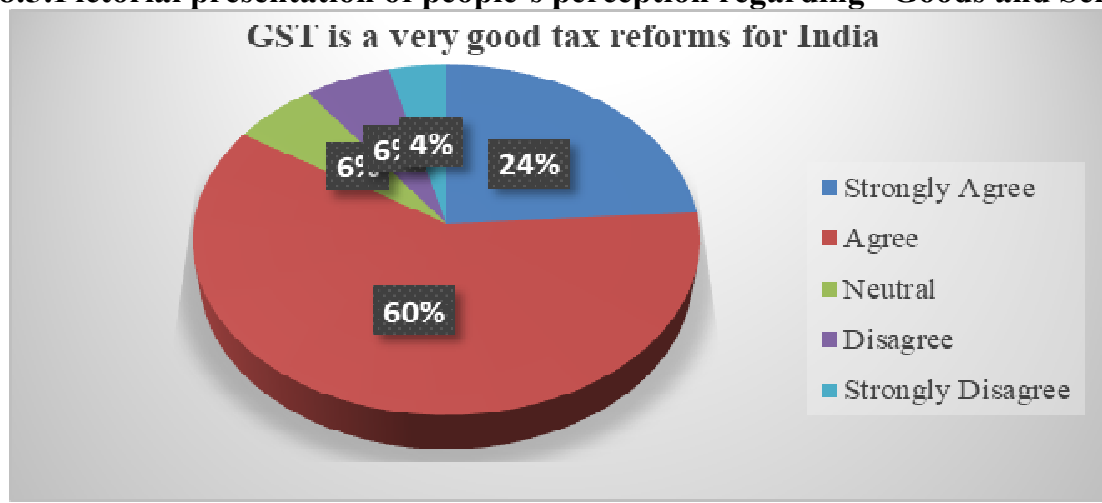

In Table 8.6, an attempt has been made to classify the respondents on the basis of their response regarding the statement "GST will favour Indian business society. " The responses are divided into five categories Strongly Agree, Agree, Neutral, Disagree and Strongly Disagree.

Table 8.6: Statement showing the support of Respondents in favour of GST

\begin{tabular}{|l|l|l|l|}
\hline Serial number & Response & Number of respondents & Percentage (\%) \\
\hline 1 & Strongly Agree & 13 & $22 \%$ \\
\hline 2 & Agree & 25 & $42 \%$ \\
\hline 3 & Neutral & 15 & $25 \%$ \\
\hline 4 & Disagree & 5 & $8 \%$ \\
\hline 5 & Strongly Disagree & 2 & $3 \%$ \\
\hline & Total & $\mathbf{6 0}$ & $\mathbf{1 0 0}$ \\
\hline
\end{tabular}

Sources: Data collected from primary sources through questionnaire method

According to the above analysis of data, majority of respondents (about $64 \%$ of the respondents) coming from different segments of the society with different academic status have shown their inclination towards favouring GST. Among the respondents only $11 \%$ do not have agreement with it. Also there are $25 \%$ of them who are neutral about it. So it can be inferred that that majority i.e. $64 \%$ agreed with the proposition. 
Figure: 8.6: Pictorial presentation showing the support of Respondents in favour of GST

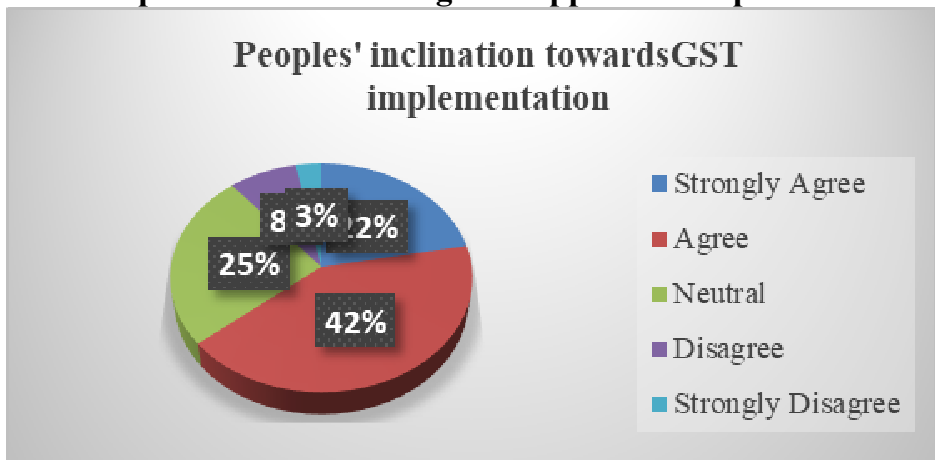

Table 8.7 strives to present characteristics of respondents on the basis of their response regarding statement "GST has increased the Tax burden on Common people". The results representing percentage share of five categories are given below:

Table. 8.7: Statement showing perception "GST has increased the Tax burden on Common people"

\begin{tabular}{|l|l|l|l|}
\hline Serial number & Response & Number of respondents & Percentage (\%) \\
\hline 1 & Strongly Agree & 10 & $17 \%$ \\
\hline 2 & Agree & 19 & $32 \%$ \\
\hline 3 & Neutral & 7 & $12 \%$ \\
\hline 5 & Disagree & 22 & $36 \%$ \\
\hline & Strongly Disagree & 2 & $3 \%$ \\
\hline & Total & $\mathbf{6 0}$ & $\mathbf{1 0 0}$ \\
\hline
\end{tabular}

Sources: Data collected from primary sources through questionnaire method

According to analysis of above data, we can infer that maximum respondents (comprising $49 \%$ of total respondents) have agreed with the statement with total disagreed respondent of $39 \%$ approximately. Actual reflection of increased tax burden is happening at present.

Figure: 8.7: Pictorial presentation supporting the statement "GST has increased the Tax burden on Common people"

'GST has increased tax burden on common people'

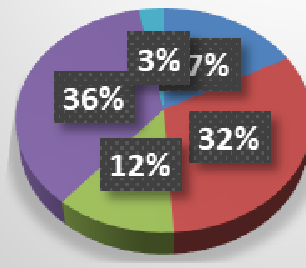

- Strongly Agree

Agree

Neutral

Disagree

Strongly Disagree

But, in actual practice, the goods and services tax (GST) is undoubtedly the most significant economic reform of recent decades. It has helped manufacturers reduce costs and compliance burden. Availability of seamless input tax credit for goods and services, barring a small list of items, reduced overall tax incidence.GST will be collected at every stage of value addition and the credit of tax paid at the previous stage will be available to set off the tax to be paid at the next stage of transaction. This will eliminate cascading of taxes. This, in turn, will lower the cost of the goods and services for the consumer.

In Table8.8, it has been tried to perceive whether introduction of GST has increased the burden of taxation on shoulders of businessmen. The respondents have been classified on the basis of their mode of agreement on this. 
Table 8.8: Categories of respondents supporting the statement "GST has increased the Tax burden on shoulders of businessmen"

\begin{tabular}{|l|l|l|l|}
\hline Serial number & Response & Number of respondents & Percentage (\%) \\
\hline 1 & Strongly Agree & 5 & $8 \%$ \\
\hline 2 & Agree & 16 & $27 \%$ \\
\hline 3 & Neutral & 10 & $17 \%$ \\
\hline 4 & Disagree & 22 & $36 \%$ \\
\hline 5 & Strongly Disagree & 7 & $12 \%$ \\
\hline & Total & $\mathbf{6 0}$ & $\mathbf{1 0 0}$ \\
\hline
\end{tabular}

Sources: Data collected from primary sources through questionnaire method

According to the above data analysis, it is found that maximum number of respondents (about $48 \%$ ) have not agreed with the statement comprising 36\% (disagreed) and 12\% (strongly disagreed with statement) respectively. Among the respondents $27 \%$ have agreed with it. So it concludes that majority have not agreed with the statement that businessmen have much tax liability as a result of introduction of GST in Indian tax regime.

Truly, GST reduces tax burden on producers and fosters growth through more production. The current taxation structure, pumped with myriad tax clauses, prevents manufacturers from producing to their optimum capacity and retards growth. GST will take care of this problem by providing tax credit to the manufacturers. Under GST, the average tax burden on the majority of goods is likely to come down, which will lead to reduction in prices, in turn resulting in more consumption. This will boost domestic demand, create more opportunities for domestic business and drive job creation.

Figure: 8.8: Pictorial presentation supporting the statement "GST has increased Tax burden on shoulders of businessmen"

GST has increased tax burden on Businessman

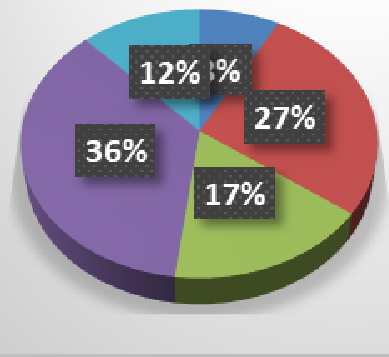

- Strongly Agree

Agree

- Neutral

- Disagree

- Strongly Disagree

In Table 8.9, we have tried to present through peoples' opinion whether India is really ready for GST implementation.

Table: 8.9: Peoples' opinion of whether India is really ready for GST implementation

\begin{tabular}{|l|l|l|l|}
\hline $\begin{array}{l}\text { Serial } \\
\text { number }\end{array}$ & Response & Number of respondents & $\begin{array}{l}\text { Percentage } \\
(\mathbf{\%})\end{array}$ \\
\hline 1 & Strongly Agree & 10 & $17 \%$ \\
\hline 2 & Agree & 25 & $42 \%$ \\
\hline 3 & Neutral & 9 & $15 \%$ \\
\hline 4 & Disagree & 15 & $25 \%$ \\
\hline 5 & $\begin{array}{l}\text { Strongly } \\
\text { Disagree }\end{array}$ & 1 & $1 \%$ \\
\hline & Total & $\mathbf{6 0}$ & $\mathbf{1 0 0}$ \\
\hline
\end{tabular}

Sources: Data collected from primary sources through questionnaire method

According to the above data, maximum respondents have agreed with the statement and $42 \%$ and $17 \%$ have agreed and strongly agreed with statement respectively. Among the respondents, $25 \%$ have not agreed with it and $15 \%$ being neutral. So it concludes that majority agreed with the statement.

In actual practice, in just two years, GST has consolidated and is delivering notable outcomes for smoother business, lower logistics costs, and easier payment of taxes in digital mode. We believe GST will be a forceful instrument for driving economic growth for India in years to come. GST is not just a tax change but a business change. 
Figure: 8.9: Pictorial presentation of Peoples' opinion of whether India is really ready for GST implementation

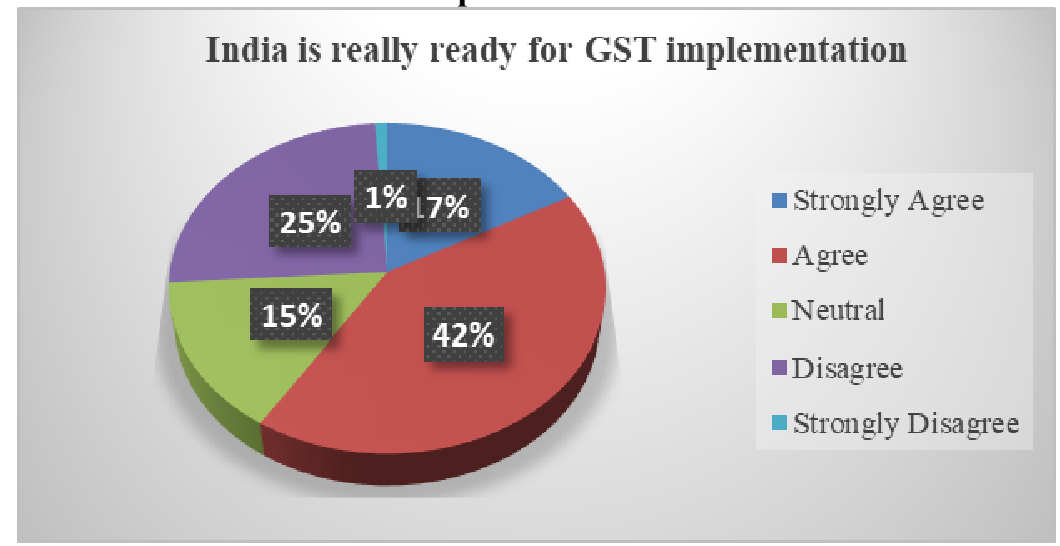

In Table8.10, an attempt has been made to classify the respondents on the basis of their responses regarding the statement 'Govt. has imposed GST on consumers without any preparation'. The given data are classified as follows:

Table 8.10: Respondents opinion regarding the statement 'Govt. has imposed GST on consumers without any preparation'

\begin{tabular}{|l|l|l|l|}
\hline Serial number & Response & Number of respondents & Percentage (\%) \\
\hline 1 & Strongly Agree & 5 & $8 \%$ \\
\hline 2 & Agree & 15 & $25 \%$ \\
\hline 3 & Neutral & 15 & $25 \%$ \\
\hline 4 & Disagree & 18 & $30 \%$ \\
\hline 5 & Strongly Disagree & 7 & $12 \%$ \\
\hline & Total & $\mathbf{6 0}$ & $\mathbf{1 0 0}$ \\
\hline
\end{tabular}

Sources: Data collected from primary sources through questionnaire method

Survey shows that maximum respondents (around30\%) have not agreed with the statement and $12 \%$ of the total respondents have strongly disagreed with statement. Among the respondents $25 \%$ have agreed with it and $8 \%$ have strongly agreed with it. So it can be inferred that majority of the respondents disagreed with the statement. In a nutshell, it can be said that most of the respondents believe that govt has plan fully introduced GST with adequate preparation.

Figure: 8.10: Pictorial presentation of opinion 'Govt. has imposed GST on consumers without any preparation'

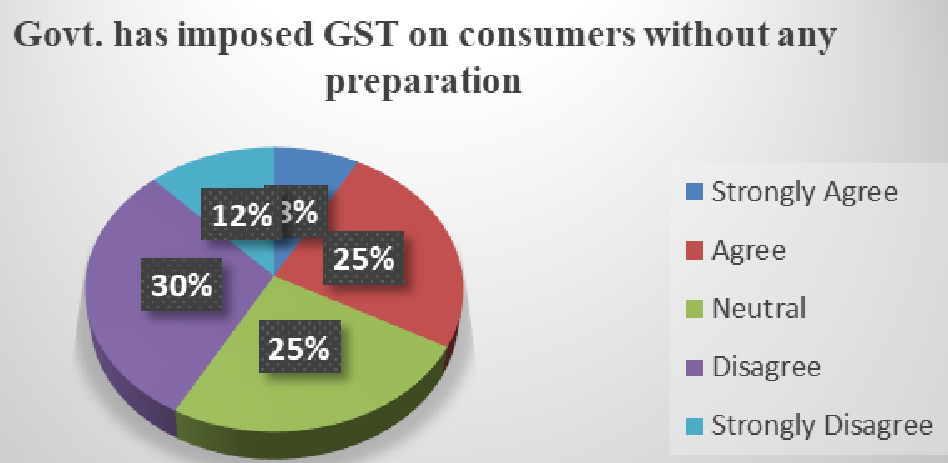

The reason behind this disagreement is very much vivid because the impetus to move towards GST stems from the inadequacies of the present system and the need for a taxation system that is economically efficient, neutral in its implication, simple to administer, encourages voluntary compliance and, most importantly, integrates India to a single common market

In Table 8.11, we have attempted to present the categories of the respondents on the basis of their perception regarding this statement 'GST will increase the inflation (prices) in the country' which are formalised below: 
Table 8.11: Respondents perception regarding statement 'GST will increase the inflation (prices) in the country'

\begin{tabular}{|l|l|l|l|}
\hline Serial number & Response & Number of respondents & Percentage (\%) \\
\hline 1 & Strongly Agree & 3 & $5 \%$ \\
\hline 2 & Agree & 22 & $37 \%$ \\
\hline 3 & Neutral & 2 & $3 \%$ \\
\hline 4 & Disagree & 27 & $45 \%$ \\
\hline 5 & Strongly Disagree & 6 & $10 \%$ \\
\hline & Total & $\mathbf{6 0}$ & $\mathbf{1 0 0}$ \\
\hline
\end{tabular}

Sources: Data collected from primary sources through questionnaire method

The result shows that maximum respondents (around45\%) have not agreed with the statement and also $37 \%$ of the total respondents have agreed with statement. Among the respondents, $10 \%$ have strongly disagreed with. So it can be concluded that majority have not agreed with the statement that GST increases inflationary pressure on the economy.

Figure: 8.11: Pictorial presentation of perception 'GST will increase the inflation (prices) in the country'

GST will increase the inflation (prices) in the country

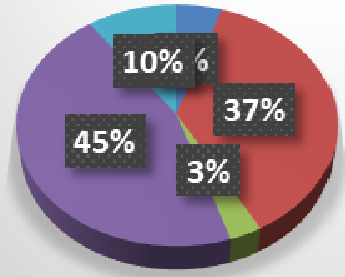

$$
\begin{aligned}
& \text { - Strongly Agree } \\
& \text { - Agree } \\
& \text { - Neutral } \\
& \text { - Disagree } \\
& \text { - Strongly Disagree }
\end{aligned}
$$

In reality, the fact is that, according to a CII report on the transition to the Goods and Services Tax (GST), its implementation led to increased efficiency for businesses by reducing their transportation time, on account of absence of state barriers.

Significantly, reality witnessed a downward movement in the wholesale prices of their supplies, as well as a fall in the retail prices of supplies, amid concerns that the tax regime may lead to a spike in inflation.

In Table 8.12, we strive to identify respondents on the basis of their perception regarding the statement 'GST is affecting small business very badly' which is presented below:

Table 8.12: Respondents perception regarding the statement ' $G S T$ is affecting small business very badly'

\begin{tabular}{|l|l|l|l|}
\hline Serial number & Response & Number of respondents & Percentage (\%) \\
\hline 1 & Strongly Agree & 11 & $18 \%$ \\
\hline 2 & Agree & 25 & $42 \%$ \\
\hline 3 & Neutral & 14 & $24 \%$ \\
\hline 4 & Disagree & 8 & $13 \%$ \\
\hline 5 & Strongly Disagree & 2 & $3 \%$ \\
\hline & Total & $\mathbf{6 0}$ & $\mathbf{1 0 0}$ \\
\hline
\end{tabular}

Sources: Data collected from primary sources through questionnaire method

Analysis revealed that most of the respondents (about $42 \%$ of total respondents) have agreed with the statement that GST is affecting small business very badly and $18 \%$ have strongly agreed with statement. Among the respondents only $13 \%$ have not agreed with it. So it will initiate us to conclude that majority of the respondents in our survey(about $60 \%$ of total respondents) in any way have agreed with the statement that GST is affecting small business very badly.

Figure: 8.12: Pictorial presentation of respondents perception 'GST is affecting small business very badly'

\section{GST is affecting small business very badly}

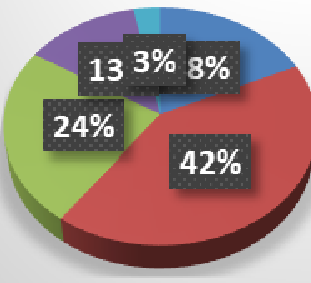

$$
\begin{aligned}
& \text { - Strongly Agree } \\
& \text { - Agree } \\
& \text { - Neutral } \\
& \text { - Disagree } \\
& \text { - Strongly Disagree }
\end{aligned}
$$


In actual practice, small businesses were exempt from paying excise under old tax laws. Goods they sold were only taxed at 5\% VAT, but now, under GST, most of the products fall under the 18\% slab, and the others are taxed at $28 \%$. In GST, only businesses with annual revenue of less than Rs 20 lakhs are exempt from registration. No, it is not mandatory for a small business owner with a turnover below Rs. 20 lakhs to get registered for the GST .Small-scale businesses which were earlier exempt from paying excise, have gone from paying VAT in the range of $5 \%-12.5 \%$ to a GST of $18 \%$, a rate which is highly disproportionate with the revenue they have.

In Table 8.13, we would like to present categories of respondents on the basis of their response regarding the statement 'GST will increase the tax collection of Government' which are given below:

Table 8.13: Respondents perception regarding the statement 'GST will increase the Tax Collection of Government'

\begin{tabular}{|l|l|l|l|}
\hline Serial number & Response & Number of respondents & Percentage (\%) \\
\hline 1 & Strongly Agree & 17 & $28 \%$ \\
\hline 2 & Agree & 27 & $45 \%$ \\
\hline 3 & Neutral & 6 & $10 \%$ \\
\hline 4 & Disagree & 7 & $12 \%$ \\
\hline 5 & Strongly Disagree & 3 & $5 \%$ \\
\hline & Total & 60 & 100 \\
\hline
\end{tabular}

Sources: Data collected from primary sources through questionnaire method

The presented survey shows that maximum respondents (comprising about $73 \%$ of the respondents) seem that GST will enhance tax revenue of government. Among the respondents, only $12 \%$ have not agreed with it.

Figure:8.13: Pictorial presentation of perception 'GST will increase the Tax Collection of Government'

\section{GST will increase the Tax Collection of Government}

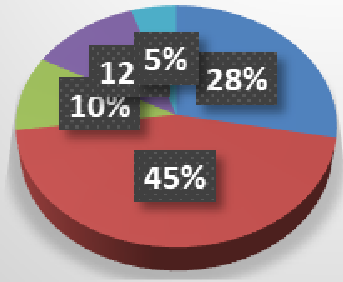

$$
\begin{aligned}
& \text { - Strongly Agree } \\
& \text { - Agree } \\
& \text { - Neutral } \\
& \text { - Disagree } \\
& \text { - Strongly Disagree }
\end{aligned}
$$

In actual practice, it has been found that Goods and services tax collections grew about $9 \%$ in December,2019 to Rs 1.03 lakh crore, from Rs 94,726 crore a year earlier(in December,2018), This improvement had come largely because of steps taken to increase compliance and check evasion.

Table 8.14 represents the respondents' perception on the basis of their response regarding the statement 'GST will cause an increase in the cost of living' which are given below:

Table 8.14: Respondents' perception regarding the statement 'GST will cause an increase in the cost of living'

\begin{tabular}{|l|l|l|l|}
\hline Serial number & Response & Number of respondents & Percentage(\%) \\
\hline 1 & Strongly Agree & 16 & $26 \%$ \\
\hline 2 & Agree & 10 & $17 \%$ \\
\hline 3 & Neutral & 19 & $32 \%$ \\
\hline 4 & Disagree & 10 & $17 \%$ \\
\hline 5 & Strongly Disagree & 5 & $8 \%$ \\
\hline & Total & 60 & 100 \\
\hline
\end{tabular}

Sources: Data collected from primary sources through questionnaire method

The surveyed data shows that maximum respondents (about 32\%) are being neutral with this statement. Only $26 \%$ of the total respondents have strongly agreed with the statement and meagre $17 \%$ have agreed with statement. Among the respondents $17 \%$ have not agreed with. But it can be inferred that in an aggregate $43 \%$ $(26 \%+17 \%)$ of the total respondents have agreed that GST will cause an increase in the cost of living . 
Figure: 8.14: Pictorial presentation of perception 'GST will cause an increase in the cost of living'

\section{GST will cause an increase in the cost of living}

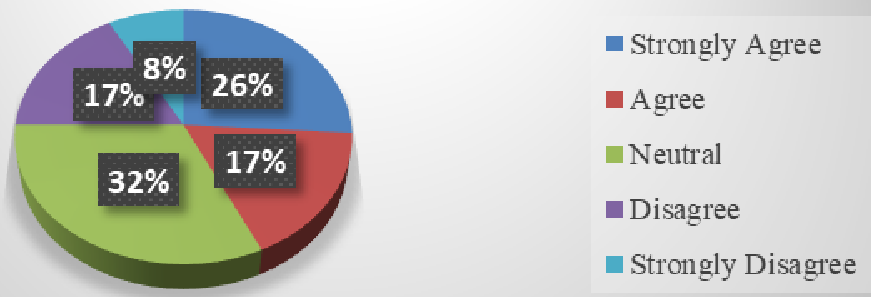

But in actual practice, picture is reverse to that. For example, if we consider $6 \%$ tax rate and GST in the following table, the resultant impact can be noticed .

Table 8.15: Impact of GST on Cost of Living

\begin{tabular}{|l|l|l|}
\hline Particulars & Before GST & After GST \\
\hline Sale by manufacturers & 10 & 10 \\
\hline Tax & $(10 \%$ of sales tax $) 1$ & $(6 \% \mathrm{GST}) 0.60$ \\
\hline Price paid by Hotel & 11 & 10.60 \\
\hline Input Tax Credit & nil & -0.60 \\
\hline Cost to Hotel & 11 & 10 \\
\hline Mark up (25\%) & 2.75 & 2.5 \\
\hline Selling price before tax & 13.75 & 12.5 \\
\hline Tax & $(6 \%$ service tax $) 0.83$ & $(6 \% \mathrm{GST}) 0.75$ \\
\hline Price paid by consumer & 14.58 & 13.25 \\
\hline Tax & 1.83 & 0.75 \\
\hline
\end{tabular}

Source: Tax review Panel

GST is a broad based consumption tax which will generally be applicable on all goods and services. The above example shows that as result of GST, price of goods to consumer will be reduced and will have a less burden on consumer.

Table 8.16 attempts to assess the respondents' perception on the basis of their response towards the statement 'Goods and Services Tax will result the products or services more expensive'.

Table: 8.16: Respondents' perception 'Goods and Services Tax will result the products or services more expensive'.

\begin{tabular}{|l|l|l|l|}
\hline Serial number & Response & Number of respondents & Percentage(\%) \\
\hline 1 & Strongly Agree & 3 & $5 \%$ \\
\hline 2 & Agree & 15 & $25 \%$ \\
\hline 3 & Neutral & 15 & $25 \%$ \\
\hline 4 & Disagree & 22 & $37 \%$ \\
\hline & Strongly Disagree & 5 & $8 \%$ \\
\hline
\end{tabular}

Sources: Data collected from primary sources through questionnaire method

The analysis suggests that maximum respondents have not agreed with the statement and that percentage is $37 \%$ and $8 \%$ have strongly disagreed with statement resulting nearly $45 \%$ of the respondents have disagreement with the statement that Goods and Services Tax will result the products or services more expensive.

Among the respondents $25 \%$ have agreed with it. Also $25 \%$ of them being neural. So it can be decided from the presented result that majority have not agreed with the statement. 
Figure 8.16: Pictorial presentation of perception 'Goods and Services Tax will result the products or services more expensive'.

\section{GST will result in the products or services more expensive.}

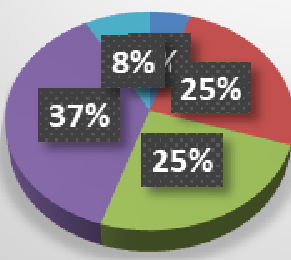

- Strongly Agree

Agree

Neutral

- Disagree

Strongly Disagree

The reality shows that after applying GST, the product will become less expensive instead of being expensive. The above example in table 7.16 will make it clear how the implementation of GST would result in reduction of prices. Hence, when the cost will reduce the price will also get reduced in spite of the same profit margin of the seller.

\section{Summary and Conclusion:}

This survey based study initiates us to have a deep insight into the "Peoples' Perception" towards the Goods and Service Tax (GST) studied particularly south Kolkata area of West Bengal State, India.

The main focus of this study is to have a general understanding about the newly introduced GST tax regime in India and also to assess the perception of general people surrounded in different segments of our society regarding the Goods and Service tax. After Analysis and Interpretation of the data, the followings findings have been emerged:

- Most of the respondents are Male.

- Majority of the respondents i.e. $48 \%$ comes under the age group $25-40$ years and $27 \%$ are comes below 25 years.

- More than 37\% respondents are related to Businessman category and 35\% are customers and students.

- The most of respondents' perception are very positive towards the GST and they are aware of GST through the mass media.

- $60 \%$ respondents are of the opinion that GST is very good tax reform for India and it is the turning point of the taxation system.

- Most of the customers perceive that GST is very beneficial in long term for economy of the country and also have effect on GDP.

- Most of the customers opine that GST is fair tax and also GST is predominantly compliance tax.

\section{Suggestions:}

* The customers suggested that there should be a smooth, transparent and simple transition provisions which is easily understandable.

* Special focus on awareness and training of all officers, professionals and assesses should be given on GST.

* Since the general public are not very much acquainted with GST , any litigation on GST issues should be proactively addressed by way of speedy redressal .

* The people are not well informed on the implementation of the GST. Therefore, in order to ensure efficient implementation of the GST, the government should come out with a proper guideline to the society on the procedures for the implementations of GST.

* Government should create more awareness among the public about GST and it advantages.

* Complicated processes must be reduced so that business can operate efficiently in the best interest of the people and for economic growth.

*Relief must be given to small scale operators and particularly reduced processes should be applicable to them.

* Lastly, the government must ensure a good management of the income or revenue collected from the GST.

The difficulty which is present in the existing Indian indirect tax system can be avoided by accepting GST. For charging tax on goods and services, GST is a better approach. The biggest problems in Indian tax system like cascading effect $\&$ tax evasion, distortion can be minimized by implementing GST. After amalgamation of local, state and central taxes, competitiveness of industry, exporter and company will increase. The additional revenue which can be generated from broaden tax base structure can be utilized for the growth of nation. In economy, tax polices play an important role because of their impact on efficiency and equity. Indirect tax reforms have been an 
essential part of the liberalization process since new economic reforms. A progressive and wellbeing oriented nation like India tries to keep a balance between direct and indirect taxes. The new tax will be a further significant breakthrough and the next logical step towards a comprehensive indirect tax reform in the country. GST is not simply VAT plus service tax, but a major improvement over the previous system of VAT and disjointed services tax. A single rate would help to maintain simplicity and transparency by treating all goods and services as equal without giving special treatment to some 'special' goods and/or services. The launch of GST would transform Asia's third largest economy into a single market for the first time.

The Government must put in more endeavours to make sure that consumers have a comprehensible understanding and develop a constructive perception towards GST, leading to its acceptance. Good understanding among customers is important as it can generate a positive perception towards the taxation policy. The West Bengal govt. as well as India govt. should make awareness among the people about GST as it is a newest tax and many of the population yet to create a fair idea about it. Govt. should put some survey and awareness camp about it. People also require demonstrating more interest towards it. In conclusion, it can be inferred with a note of optimism that the implementation of GST is a changing face of India which is a welcome move and the government should be well equipped for that which is a indication of fast paced economy.

\section{References:}

1. AnshuAhuja(2017),Perceptions of people towards goods and services tax, Kaav International Journal of Economics, Commerce \& Business Management, Jul - Sep 2017 Volume: 4 Issue: 3.

2. Ehtisham Ahamad and Satya Poddar(2009), "Goods and Service Tax Reforms and Intergovernmental Consideration in India”, “Asia Research Center",LSE,2009.

3. Girish Garg, (2014), "Basic Concepts and Features of Good and Service Tax in India", International Journal of scientific research and management (IJSRM), Volume, 2, Issue, 2 Pages, 542-549.

4. Gupta Nishita ( 2014), Goods and Service Tax : Its implementations on Indian economy, International Research Journal of Commerce Arts and Science, volume 5, Issue 3.

G. Ramkumar (2017), Impact of GST on consumer spending ability in Chennai city, Primax International Journal of

5. Jaiprakash. (2014), Indirect tax reforms in India and way ahead for GST. International Journal of Computing and Corporate Research.

6. Jaspreet Kaur, (2016), "Goods and service tax (GST) and its impact, International Journal of Applied Research,vol. 2(8): pp. 385-387.

7. Kumar Nitin (2014), GST in India : A way forward, Global Journal of Multi-disciplinary Studies, Vol 3, Issue 6 , May 2014.

8. Mawuli, A., (2014), "Goods and Service Tax- an Appraisal" Paper presented at the the PNG Taxation Research and Review Symposium, Holiday Inn, Port Moresby, pp.29-30.

9. Nitin Kumar (2014). Goods and Services Tax in India- A way forward. In Global Journal of Multidisciplinary Studies, Volume 3, Issue 6, May 2014. Retrieved from the URL on 15 August 2015.

10. Nishita Gupta(2014), Goods and Services Tax: Its implementation on Indian economy, CASIRJ Volume 5 Issue 3 ,pp.126-133.

11. Pinki, Supriya Kamna, Richa Verma(2014), Goods and Service Tax"--Panacea For Indirect Tax System in India , Tactful Management Research Journal', Vol12, issue 10 July,.

12. Palil, M. R., \& Ibrahim, M. A. (2011). The Impact of Goods and Services Tax (GST) on Middle Income Earners in Malaysia, World Review of Business Research, vol.1(3), pp.192-206.

13. R. Vasanthagopal (2011), "GST in India: A Big Leap in the Indirect Taxation System", International Journal of Trade, Economics and Finance, vol. 2, No. 2.

14. R Karthick, E. H. (2017). A Study on consumer perception towards GST in Kanchipuram district. PARIPEX ${ }^{-}$INDIAN JOURNAL OF RESEARCH, pp.82-83.

15. Vineet Chouhan, Pushpkant Shakdwipee and Shagufta Khan (2017), Measuring Awareness about Implementation of GST: A Survey of Small Business Owners of Rajasthan, Pacific Business Review International, vol.9, Issue 8, pp116-25, Feb. 2017.

Website:

16. www.gstindia.com

17. https://en.wikipedia.org

18. www.gstn.org

19. www.cbec.gov.in

20. www.gstcounsil.gov.in 